\title{
Erratum to: Genetic Counseling and Testing for FMRI Gene Mutations: Practice Guidelines of the National Society of Genetic Counselors
}

Brenda Finucane - Liane Abrams - Amy Cronister • Alison D. Archibald • Robin L. Bennett • Allyn McConkie-Rosell

Published online: 21 September 2012

(C) National Society of Genetic Counselors, Inc. 2012

Erratum to: J Genet Counsel DOI 10.1007/s10897-012-9524-8

The research affiliation of author Alison D. Archibald was omitted from the publication.

Murdoch Childrens Research Institute, Melbourne, Victoria, Australia

The online version of the original article can be found at http://dx.doi.org/ 10.1007/s10897-012-9524-8.

(C) 2011 National Society of Genetic Counselors. All rights reserved. This document may not, in whole or in part, be reproduced, copied or disseminated, entered into or stored in a computer database or retrieval system, or otherwise utilized without the prior written consent of the NSGC.

B. Finucane $(\bowtie)$

Genetic Services at Elwyn,

Elwyn, PA, USA

e-mail: brenda_finucane@elwyn.org

L. Abrams

National Fragile X Foundation,

Walnut Creek, CA, USA

\section{A. Cronister}

Integrated Genetics,

Phoenix, AZ, USA

\section{A. D. Archibald}

Murdoch Childrens Research Institute \& Victorian Clinical

Genetics Services,

Melbourne, Victoria, Australia

\section{R. L. Bennett}

Division of Medical Genetics,

University of Washington Medical Center,

Seattle, WA, USA

A. McConkie-Rosell

Division of Medical Genetics, Duke University Medical Center,

Durham, NC, USA 